\title{
Perceptions of Field Instructors: What Skills Are Critically Important in Managed Care and Privatized Environments?
}

\author{
Michael N. Kane \\ Elwood R. Hamlin II \\ Wesley Hawkins
}

\begin{abstract}
There is an increasing demand for social work practitioners to work in managed care and privatized environments. In an attempt to build social work curriculum and identify important competencies needed in contemporary service environments, researchers investigated South Florida field instructors' $(N=79)$ perceptions of necessary knowledge and skill to work in environments affected by privatization and managed care. This study's findings indicate that field instructors (98\%) identified documentation as the most critically important skill for any social work position. Additionally, respondents identified intervention evaluation (95\%), timefocused and needs-based assessments strategies (94\%), and evaluation of progress through outcome measures (94\%) as other critically important skills for current and future practitioners.
\end{abstract}

Keywords: Managed care, practicum, social work education, field instructors

W

hether functioning independently or as part of a multi-disciplinary team, social workers have provided innovative helping services in various settings over the decades. Many of these sites and services are undergoing change, development, and restructuring as a result of government and corporate "obsession with cost" (Davis \& Meier, 2000, p.10). Once primarily employed in the public and private not-for-profit sector, social workers have become increasingly more present in private for-profit settings (Ginsberg, 2000). Over the decades the profession has successfully adapted to various new service environments. Currently, the challenge to the profession may extend beyond environmental adaptation to include its knowledge and skills base.

The delivery of services within both the public and private sectors of health, mental health, and social services has changed dramatically in the past decade and will likely continue to undergo further change (Berkman, 1996; Edinburg \& Cottler, 1995; Motenko et al., 1995; Oss, 1996; Perloff, 1998; Rosenberg, 1998; Scuka, 1994; Vernon, 1998; Volland, Berkman, Stein \& Vaghy, 1999; White, Simmon \& Bixby, 1993). Private health, mental health, and social agencies have adopted service delivery models which incorporate cost-controlling measures while

Michael N. Kane, Ph.D., MSW, M. DIV. is Assistant Professor; Elwood R. Hamlin II, D.S.W. and Wesley Hawkins, Ph.D. are Associate Professors, Florida Atlantic University, Boca Raton, Florida, USA . 
attempting to provide quality intervention (Borenstein, 1990; Corcoran \& Vandiver, 1996). Public health, mental health, and social service agencies have also been increasingly privatized with the goal of controlling escalating costs and providing effective intervention (Elias \& Navon, 1998; Beinecke, Goodman \& Lockhart, 1998). Most Americans desire the highest quality, cutting-edge services. However, 21st century fiscal realities inhibit their widespread implementation. Federal, state, and local governments representing the sentiments of taxpayers, employers, and insurance companies are sending messages to service providers and service recipients that unrestricted access to service is a luxury that is not economically supportable (Fletcher, 1999; McEntee, 1993). Therefore, managed care models have emerged as prominent methods for allocating and rationing resources. Rationing procedures such as utilization review have become the principal methods of dispensing expensive and scarce resources. Underlying these models of service delivery are two assumptions: (a) unnecessary services are being provided to people who do not need services, and (b) inappropriately intensive and expensive services are provided when less intensive services would be sufficient (Kapp, 1999; Rose, 1996).

While the nation has opted for marketplace health, mental health, and social service delivery, current service providers have struggled to remain responsive and competitive by acquiring new knowledge and skills. Future health and mental health practitioners are facing new demands as a result of delivery system changes (Coggan, 1997; Fletcher, 1999; Hagland, 1996).

Social workers have traditionally been present in health care venues. Given the profession's dominant position in the provision of mental health and social services and the prevalence of these managed care models, it is critically important that educators and curriculum stakeholders evaluate curricula that will prepare future practitioners for these new and emerging models of service delivery. There are many sources that may support curriculum development and evaluation of necessary skills and knowledge in the current service environment. Field instructors are one critical source to offer important information for social work curriculum evaluation (Alperin, Gray \&Wik, 1991).

\section{SOCIAL WORK AND CURRENT MODELS OF SERVICE DELIVERY}

The profession has begun to focus attention on managed care and privatized models of service delivery. The Council on Social Work Education has established a program research commission that questions whether curricula address today's practice world. Furthermore, project "Beyond Year 2010: Public Health Social Work Practice” intends to examine practice within the context of managed care (O'Neill, 2000). The literature has tended to focus heavily on the ethical conundrums and legal issues associated with current service delivery methods (Callahan, 1998; Davidson \& Davidson, 1998; Houston-Vega, Nuehring, with Daguio, 1997; Madden, 1998; Munson, 1998; Reamer, 1998; Rock \& Congress, 1999), preferred models of clinical practice in the current service delivery environment (Corcoran \& Vandiver, 1996; Kadushin, 1996; Mitchell, 1998; Poole, 1996), the restrictive aspects of service rationing (Callahan, 1998; McQuaide, 1999; Sessions, 1998), and enduring practitioner obligations to clients (Davidson, Davidson \& Keigher, 1999; Houston-Vega et al., 1997; Madden, 1998; Reamer, 1998; Watt \& Kallmann, 1998). 
This important body of literature appears to focus on the underlying philosophical and value conflicts that exist between professional social work and current service delivery trends. Practitioners, educators, and clients' negative attitudes toward current models of managed care fill scholarly and popular literature (Berger \& Ai, in press-a). Yet, in spite of these negative perceptions and attitudes, rationing and limited service delivery are increasing and will continue to be an integral part of health, mental health, and social service delivery (Berger \& Ai, in press-b).

At the heart of the matter may be the tension that exists between social work's preferred models of practice and managed care's approach to service delivery. Many current social work writers and educators favor postmodernist models of practice (Parkeck, Murphy \& Choi, 1994), such as empowerment (Lee, 1994) or strength-based perspectives (Cowger, 1994; Rapp, 1998; Saleebey, 1996). Managed care is a deficit-focused service delivery system that operates on the medical model (Kane, Houston-Vega \& Nuehring, in press). Reconciling postmodernist models to a medical model service delivery system is a challenge that current and future practitioners cannot avoid if they expect to remain consistent with social work ethical obligations and remain competitive in the marketplace. Kelly (1998) suggests that the postmodernist key to this practitioner dilemma lies in the ability to understand the reality of clients as well as the reality of managed care and utilization review. Based on these realities, practitioners communicate by "talking in two voices" (Kelly, 1998, p. 437). Essentially, practitioners communicate client needs to managed care companies in the language of utilization reviewers. Aside from some potential ethical concerns with this strategy, the more distressing reality for practitioners and clients is managed care's predictable focus on profit and cost, and the limited attention given to the best interests of clients or the expertise of practitioners. Davis and Meier (2000) suggest that managed care does not operate from a clinical perspective of service delivery but rather from a business model. These business models inform business activities and support strategies to maximize profits, yet may have limited effectiveness in providing real services to real people in need.

Educators and curriculum stakeholders find themselves in a difficult position as they observe rapidly changing service environments and multiple new demands that are placed on practitioners. The employment market requires specialized skills for social workers. Educators struggle to find the best methods for infusing necessary knowledge and skills that address current needs, while remaining faithful to the profession's values, knowledge, and skill base. Over the past few years, social work educators have been encouraged to include specific knowledge and skills in educational curricula to ensure competency in this new service delivery environment (Kadushin, 1997; Raskin \& Blome, 1998; Rosenberg, 1998; Shera, 1996; StromGottfried, 1997; Volland et al., 1999).

Although there is an abundance of theoretical or position literature, few empirical studies exist that identify the specific knowledge and skills necessary for current service delivery environments. Vandivort-Warren (1996) developed a list of knowledge and skills as a result of work with several social work focus groups throughout the United States. Group participants identified critically important items which include treatment skills based on diagnostic protocols, research skills 
using client outcome measures, conceptualizing treatment as best outcomes in a cost-conscious environment, business/financial knowledge and skills, and understanding market forces.

Other literature has suggested that social work education might include knowledge of managed care models and privatization (Brooks \& Riley, 1996; Kadushin, 1997; Raskin \& Blome, 1998; Strom-Gottfried, 1997; Volland et al., 1999), outcomes research (Corcoran \& Gingerich, 1994; Strom-Gottfried, 1997; Volland et al., 1999), documentation (Brooks \& Riley, 1996; Raskin \& Blome, 1998; Volland et al., 1999), needs-based assessments (Brooks \& Riley, 1996; Kadushin, 1997; Raskin \& Blome, 1998; Strom-Gottfried, 1997; Volland et al., 1999), and case management strategies (Volland et al., 1999). Volland et al. (1999) propose this can be accomplished if field instruction and classroom education become better integrated.

The field practicum has been a critically important and traditional context for social work training. However, field sites currently face several dilemmas. Because student services are not reimbursable through Medicaid and other forms of insurance (Donner, 1998; Kane et al., in press), some agencies have opted to eliminate students in field practicum as they are no longer beneficial to the agency (Raskin \& Blome, 1996). Field instructors have little time for intensive supervision (Berkman, 1996). Non-billable time spent in student-supervision by a field instructor reduces the time spent in providing reimbursable services for agencies. And from a bold educational perspective, Berger and Ai (in press-a) reason that only field settings that incorporate managed care models should be used as practicum sites, as only they will adequately prepare future practitioners.

Clearly, field instructors are the bridges between educators, students, agencies, and payers. They provide important information regarding critical knowledge and skill for current and future service delivery based on their clinical and agency knowledge and experience. This study sought to identify field instructors' perceptions of critically important knowledge and skills for preparedness to work in these changing environments.

\section{METHODOLOGY}

Respondents: South Florida has several universities with social work programs. Because of the geographic proximity of these institutions, field instructors may supervise BSW and MSW students from more than one university. A listing of field instructors was obtained from one South Florida university. This university has an accredited BSW program and is working to establish candidacy status with CSWE for its new MSW program.

This study used exploratory, self-administered survey methodology. Dillman (1978) suggests that researchers should monitor response rates following the first distribution of self-administered instruments, complete with cover letters. Additionally, follow-up mailings should be sent to ensure an acceptable response rate. All 109 field instructors identified on this university list were contacted by mail and requested to complete an anonymous questionnaire. No identifying information was elicited to better ensure the confidentiality of responses. A form letter accompanied the questionnaire and explained that this survey's findings would assist in developing a MSW curriculum responsive to current service delivery 
needs. The letter explained that the investigators were interested in respondents' attitudes and perceptions regarding the knowledge and skills necessary for practice in current service delivery environments. Two of the 109 cover letters and instruments were returned as undeliverable. Within two weeks, 54 instruments were returned. Since there were no identifying marks or codes on these returned instruments and to solicit a larger response, a second mailing was completed within the month. Respondents were told not to resubmit the instrument if they had already returned one. An additional 19 completed instruments were returned within one month. Six additional completed instruments were returned within 10 weeks, which resulted in a response rate of $74 \%(N=79)$. Rubin and Babbie (2000) indicate that a response rate of $50 \%$ is acceptable, $60 \%$ is good, and $70 \%$ is very good.

Instrument: The instrument consisted of two parts. The first part contained demographic information pertaining to the field instructors and their agencies. The second part consisted of Likert format items that were developed based on content from the literature, particularly from the findings of Volland et al. (1999), who (1999) identified several key areas for social work curricula. The identified skills included familiarity with biopsychosocial treatment modalities, policies/regulations, population-specific terminology, networking, financial management skills, assessment and interviewing skills, documentation, outcome evaluation, and data management. Researchers developed items from this list of skills. Instrument items sought to identify the field instructors' perceptions regarding the importance of these skills and the necessary knowledge for the current service delivery climate.

The instrument was piloted using practitioners and field supervisors and on average took approximately 10 minutes to complete. An expert panel of social work educators, practitioners, and organization utilization reviewers established face validity for all items.

Reliance on field instructor respondents limited this study. Other sources for future curriculum development must be investigated to ensure a complete representation of what is necessary in contemporary service delivery climates. These sources may include employers, organizations, educators, students, and managed care organizations. As with all anonymous self-reporting studies, investigators could not determine whether non-responders were significantly different from responders.

\section{FINDINGS}

The majority of survey respondents were white (85\%), female (72\%), with MSW degrees (84\%). About half worked in private, not-for-profit social service agencies (54\%) and had the shared responsibilities of direct client contact and some supervisory function. The sample and NASW demographics appear similar for these variables. The typical NASW member was white $(87.9 \%)$, female $(79.4 \%)$, and holds an MSW (85.5\%) (Gibelman \& Schervish, 1997). Unlike this sample, only $29.9 \%$ of NASW members work in the private not-for-profit sector and $48.7 \%$ of NASW members work in the private for-profit sector (Gibelman \& Schervish, 1997). Other demographic information is contained in Table 1. 


\begin{tabular}{|c|c|c|}
\hline & $\mathbf{N}$ & $\%$ \\
\hline \multicolumn{3}{|l|}{ Gender } \\
\hline Female & 57 & 72 \\
\hline Male & 22 & 28 \\
\hline \multicolumn{3}{|l|}{ Race/Ethnicity } \\
\hline African American & 4 & 5 \\
\hline Carribean Black American & 0 & 0 \\
\hline Asian/Pacific Islander & 0 & 0 \\
\hline Hispanic/Latino & 4 & 5 \\
\hline Native American/American Indian & 1 & 1 \\
\hline Caucasian/White & 67 & 85 \\
\hline Other & 3 & 4 \\
\hline \multicolumn{3}{|l|}{ Highest Degree Earned } \\
\hline MSW & 66 & 84 \\
\hline Social Work Doctorate & 1 & 1 \\
\hline Other & 12 & 15 \\
\hline \multicolumn{3}{|l|}{ Years in Social Work } \\
\hline Under 2 & 2 & 3 \\
\hline $2-5$ & 15 & 19 \\
\hline $6-10$ & 26 & 33 \\
\hline $11-15$ & 11 & 14 \\
\hline 16 or more & 24 & 30 \\
\hline \multicolumn{3}{|l|}{ Employment } \\
\hline Private-for-profit & 15 & 19 \\
\hline Private-not-for-profit & 43 & 54 \\
\hline Public-Federal & 2 & 3 \\
\hline Public-State & 6 & 8 \\
\hline Public-County & 11 & 14 \\
\hline \multicolumn{3}{|l|}{ In Private Practice } \\
\hline Yes & 14 & 18 \\
\hline No & 63 & 82 \\
\hline \multicolumn{3}{|l|}{ Primary Employment Setting } \\
\hline Health & 12 & 16 \\
\hline Mental Health/Substance Abuse & 15 & 19 \\
\hline Courts/Justice System & 10 & 13 \\
\hline School & 5 & 6 \\
\hline Residential Facility & 2 & 3 \\
\hline Social Service Agency & 24 & 30 \\
\hline Other & 9 & 11 \\
\hline \multicolumn{3}{|l|}{ Primary Clients Served } \\
\hline Children/Adolescents & 12 & 15 \\
\hline Families & 6 & 8 \\
\hline Adults & 25 & 32 \\
\hline Older Persons & 7 & 9 \\
\hline Mix of Above & 29 & 37 \\
\hline \multicolumn{3}{|l|}{ Years of Supervising BSW interns } \\
\hline$<2$ & 29 & 37 \\
\hline $2-5$ & 28 & 35 \\
\hline $6-10$ & 9 & 11 \\
\hline$>10$ & 13 & 16 \\
\hline
\end{tabular}


Table 1: Characteristics of Sampled Field Instructors ( $N=79$ ) (cont.)

\begin{tabular}{|c|c|c|}
\hline & $\mathbf{N}$ & $\%$ \\
\hline \multicolumn{3}{|l|}{ Years of Supervising MSW Interns } \\
\hline$<2$ & 42 & 53 \\
\hline $2-5$ & 16 & 20 \\
\hline $6-10$ & 5 & 6 \\
\hline$>10$ & 15 & 19 \\
\hline \multicolumn{3}{|l|}{ Primary Employment Function } \\
\hline Administrative & 17 & 22 \\
\hline Middle Management/Supervisor & 9 & 11 \\
\hline Supervisor with Significant Client Contact & 30 & 38 \\
\hline Front Line Social Worker & 18 & 23 \\
\hline Other & 5 & 6 \\
\hline
\end{tabular}

Table 2 provides a rank ordering of field instructors' perceptions of the importance of knowledge and skill in the current service delivery environment. Respondents provided information on knowledge and skills they believed to be critically important in current service delivery environments. Documentation (98\%) was perceived as the most critically important skill, followed by intervention evaluation (95\%), time-focused and needs-based assessments (94\%), evaluation of progress by outcome measures (94\%), solution-focused methods (86\%), interdisciplinary collaboration (86\%), case management skills (86\%), knowledge of insurance (84\%), knowledge of managed care (84\%), and knowledge of health care coverage and financing (84\%). Sixty-six percent of respondents identified macro-change skills or knowledge of Medicare/Medicaid as important.

Table 2: Rank Order of Field Instructors' Perceptions of the Importance of Knowledge and Skills in the Current Service Delivery Environment

\begin{tabular}{|c|c|c|c|c|}
\hline & \multicolumn{2}{|c|}{ Agree } & \multicolumn{2}{|c|}{ Disagree $^{* * *}$} \\
\hline & $\mathrm{N}$ & $\%$ & $\mathrm{~N}$ & $\%$ \\
\hline 1. Documentation & 77 & 98 & 1 & 1 \\
\hline 2. Intervention Evaluation & 75 & 95 & 2 & 3 \\
\hline 3. Evaluation of Progress by Outcome Measures & 74 & 94 & 3 & 4 \\
\hline 4. Time-focused and Needs-based Assessment & 74 & 94 & 4 & 5 \\
\hline 5. Solution-focused Methods & 68 & 86 & 7 & 9 \\
\hline 6. Interdisciplinary Collaboration & 68 & 86 & 9 & 11 \\
\hline 7. Case Management & 67 & 85 & 9 & 11 \\
\hline 8. Agency-specific Terminology & 66 & 84 & 11 & 14 \\
\hline 9. Knowledge of Insurance & 66 & 84 & 11 & 14 \\
\hline 10. Knowledge of Managed Care & 66 & 84 & 11 & 14 \\
\hline 11. Healthcare Coverage \& Financing & 66 & 84 & 10 & 13 \\
\hline 12. Knowledge of Entitlement Programs & 65 & 82 & 10 & 13 \\
\hline 13. Brief Intervention & 62 & 79 & 14 & 18 \\
\hline 14. Knowledge of the Business Side of Agency Services & 60 & 76 & 16 & 20 \\
\hline 15. Demonstrating Cost-effectiveness of Performance & 57 & 72 & 18 & 23 \\
\hline 16. Knowledge of Medicare \& Medicaid & 52 & 66 & 23 & 29 \\
\hline 17. Macro-change Skills & 52 & 66 & 23 & 29 \\
\hline
\end{tabular}




\begin{tabular}{|c|c|c|c|c|c|c|c|}
\hline \multirow[t]{2}{*}{ Skill } & \multirow{2}{*}{$\begin{array}{c}\text { Years of } \\
\text { Experience }\end{array}$} & \multicolumn{2}{|c|}{ Agree } & \multicolumn{2}{|c|}{ Disagree } & \multirow[b]{2}{*}{$\mathrm{X}^{2}$} & \multirow[b]{2}{*}{$\mathbf{P}$} \\
\hline & & $\mathrm{N}$ & $\%$ & $\mathbf{N}$ & $\%$ & & \\
\hline \multirow[t]{3}{*}{ Documentation } & $<5$ & 17 & 100 & 0 & 0 & & \\
\hline & $6-10$ & 25 & 96 & 1 & 4 & & \\
\hline & $11+$ & 34 & 100 & 0 & 0 & 1.98 & .37 \\
\hline \multirow{3}{*}{$\begin{array}{l}\text { Intervention } \\
\text { Evaluation }\end{array}$} & $<5$ & 17 & 100 & 0 & 0 & & \\
\hline & $6-10$ & 25 & 96 & 1 & 4 & & \\
\hline & $11+$ & 33 & 100 & 0 & 0 & 1.94 & .37 \\
\hline \multirow{3}{*}{$\begin{array}{l}\text { Evaluation of } \\
\text { Progress by Out- } \\
\text { come Measures }\end{array}$} & $<5$ & 17 & 100 & 0 & 0 & & \\
\hline & $6-10$ & 25 & 96 & 1 & 4 & & \\
\hline & $11+$ & 32 & 97 & 1 & 3 & 0.62 & .72 \\
\hline \multirow{3}{*}{$\begin{array}{l}\text { Time-focused \& } \\
\text { Needs-based } \\
\text { Assessments }\end{array}$} & $<5$ & 16 & 94 & 1 & 6 & & \\
\hline & $6-10$ & 26 & 100 & 0 & 0 & & \\
\hline & $11+$ & 31 & 91 & 3 & 9 & 2.35 & .31 \\
\hline \multirow{3}{*}{$\begin{array}{l}\text { Solution-focused } \\
\text { Methods }\end{array}$} & $<5$ & 15 & 88 & 2 & 12 & & \\
\hline & $6-10$ & 23 & 92 & 2 & 8 & & \\
\hline & $11+$ & 29 & 91 & 3 & 9 & 0.16 & .91 \\
\hline \multirow{3}{*}{$\begin{array}{l}\text { Interdisciplinary } \\
\text { Collaboration }\end{array}$} & $<5$ & 15 & 88 & 2 & 12 & & \\
\hline & $6-10$ & 22 & 85 & 4 & 15 & & \\
\hline & $11+$ & 30 & 91 & 3 & 9 & 0.55 & .76 \\
\hline \multirow{3}{*}{$\begin{array}{l}\text { Case } \\
\text { Management }\end{array}$} & $<5$ & 14 & 88 & 2 & 12 & & \\
\hline & $6-10$ & 22 & 85 & 4 & 15 & & \\
\hline & $11+$ & 30 & 91 & 3 & 9 & 0.55 & .76 \\
\hline \multirow{3}{*}{$\begin{array}{l}\text { Agency- } \\
\text { specific } \\
\text { Terminology }\end{array}$} & $<5$ & 16 & 94 & 1 & 6 & & \\
\hline & $6-10$ & 20 & 77 & 6 & 23 & & \\
\hline & $11+$ & 29 & 88 & 4 & 12 & 2.71 & .26 \\
\hline \multirow{3}{*}{$\begin{array}{l}\text { Knowledge of } \\
\text { Insurance }\end{array}$} & $<5$ & 17 & 100 & 0 & 0 & & \\
\hline & $6-10$ & 20 & 77 & 6 & 23 & & \\
\hline & $11+$ & 28 & 85 & 5 & 15 & 4.44 & .11 \\
\hline \multirow{3}{*}{$\begin{array}{l}\text { Knowledge of } \\
\text { Managed Care }\end{array}$} & $<5$ & 16 & 100 & 0 & 0 & & \\
\hline & $6-10$ & 22 & 88 & 3 & 12 & & \\
\hline & $11+$ & 24 & 75 & 8 & 25 & 5.49 & .06 \\
\hline \multirow{3}{*}{$\begin{array}{l}\text { Healthcare } \\
\text { Coverage \& } \\
\text { Financing }\end{array}$} & $<5$ & 17 & 100 & 0 & 0 & & \\
\hline & $6-10$ & 20 & 80 & 5 & 20 & & \\
\hline & $11+$ & 28 & 85 & 5 & 15 & 3.67 & .16 \\
\hline \multirow{3}{*}{$\begin{array}{l}\text { Knowledge of } \\
\text { Entitlement } \\
\text { Programs }\end{array}$} & $<5$ & 15 & 94 & 1 & 6 & & \\
\hline & $6-10$ & 22 & 85 & 4 & 15 & & \\
\hline & $11+$ & 27 & 85 & 5 & 15 & 0.92 & .63 \\
\hline \multirow{3}{*}{$\begin{array}{l}\text { Brief } \\
\text { Intervention }\end{array}$} & $<5$ & 13 & 77 & 4 & 23 & & \\
\hline & $6-10$ & 22 & 88 & 3 & 12 & & \\
\hline & $11+$ & 26 & 79 & 7 & 21 & 1.14 & .57 \\
\hline Knowledge of the & $<5$ & 13 & 81 & 3 & 19 & & \\
\hline Business Side of & $6-10$ & 19 & 73 & 7 & 27 & & \\
\hline Agency Services & $11+$ & 27 & 82 & 6 & 18 & 0.74 & .69 \\
\hline
\end{tabular}


Table 3: Years of Social Work Experience and Perceptions of Knowledge and Skill Importance (cont.)

\begin{tabular}{|llllllll|}
\hline Skill & Years of & \multicolumn{2}{c}{ Agree } & \multicolumn{2}{c|}{ Disagree } & \multirow{2}{*}{ ( } \\
& Experience & N & \% & N & \% & X $^{2}$ & P \\
\hline Demonstrating & $<5$ & 15 & 88 & 2 & 12 & & \\
Cost-effectiveness & $6-10$ & 17 & 68 & 8 & 32 & & \\
Performance & $11+$ & 25 & 78 & 7 & 22 & 2.38 & .31 \\
Knowledge of & $<5$ & 12 & 71 & 5 & 29 & & \\
Medicare \& & $6-10$ & 15 & 63 & 9 & 37 & & \\
Medicaid & $11+$ & 24 & 73 & 9 & 27 & 0.71 & .70 \\
Macro-change & $<5$ & 10 & 67 & 5 & 33 & & \\
Skills & $6-10$ & 21 & 81 & 5 & 19 & & \\
& $11+$ & 20 & 61 & 13 & 39 & 2.80 & .25 \\
\hline
\end{tabular}

Years of professional experience were collapsed into three options: less than five years of experience, six to 10 years of experience, and 11 or more years of experience. Since social work experience might be expected to be a critical component in determining perceptions of skill and knowledge importance, $\chi^{2}$ statistics were computed for all 17 items. Because there were 17 individual statistical tests, the possibility of family-wide error rate existed. To control for a family-wide error rate, the significance level was adjusted using the Bonferroni technique. The starting statistical significance of 0.05 was divided by 17 , which resulted in a new significance level of 0.00294 . Table 3 contains cross-tabulations and $\chi^{2}$ statistics for all items.

Interestingly, none of the $\chi^{2}$ statistics were significant, indicating that there was no significant disagreement among field instructors with various levels of social work experience. The only item approaching significance was "knowledge of managed care" ( $p=0.06$ ). Of the total respondents, $84 \%$ agreed that knowledge of managed care was a critically important area of knowledge. However, while all of the respondents with less than five years of professional experience and $88 \%$ of respondents with six to 10 years of experience indicated that it was a critically important skill, only $75 \%$ of the respondents with 11 or more years agreed.

When the level of professional experience was statistically controlled, there were no significant differences among the groups. Nonetheless, trends were visible in some variables, particularly variables centering on business issues. Most noteworthy was the perception difference in the importance of knowledge of managed care and knowledge of insurance. All field instructors with less than five years of experience perceived these items as critically important, while field instructors with more experience did not unanimously concur. Additionally, other business-related variables, such as knowledge of healthcare financing and demonstrating cost effectiveness in performance, were more likely to be perceived as critically important by field instructors with less than five years of experience. Even though there were no statistical differences among the levels of experience, it appears that these variables were particularly important to field instructors with less professional experience. 


\section{IMPLICATIONS AND CONCLUSIONS}

Field instructors are one of several critically important sources of information for social work educators and curriculum stakeholders. Little empirical data exists confirming the importance of specific skills for managed care and privatized environments. From a literature search, various skills associated with managed care environments were identified. Respondent field instructors were asked to identify those skills and knowledge they thought to be the most important for current service delivery climates. Critically important skills identified by field instructors included documentation, intervention evaluation, time-focused and needs-based assessment, and outcome measures. Other important skills included solution-focused methods, interdisciplinary collaboration, and case management. Knowledge of insurance, managed care, health care coverage, and financing were also identified as important. While the literature identified knowledge of Medicare and Medicaid and macro-change skills as critically important, study respondents did not overwhelmingly agree. Finally, there were no significant differences in critically important skill perceptions based on years of experience. These findings offer important insights into current service delivery environments and have potential implications for social work education.

Because social work is a value-based profession, social work educators filter knowledge and skill through the profession's Code of Ethics. The profession's mission, as identified in the Code of Ethics, is to "enhance human well-being and help meet the basic human needs of all people, with particular attention to the needs and empowerment of people who are vulnerable, oppressed, and living in poverty" (National Association of Social Workers, 1996, p. 1). With such intention, educators and practitioners interact with multiple systems, including clients, managed care organizations, privatized environments, insurance companies, and utilization reviewers. While social work education favors postmodernist models of empowerment and strength-based perspectives, managed care seeks to find the deficit in covered lives that can be quickly, cheaply, and efficiently remedied. But perhaps most importantly, managed care and privatized environments function on a business model. Their focus is primarily the cost of services. Clients' needs and practitioners' expertise appear to be secondary considerations (Davis \& Meier, 2000). Despite identified shortcomings, managed care and privatized environments appear to be here to stay. There appear to be no other viable options on the horizon to control escalating costs. This, coupled with society's general unwillingness to provide limitless and expensive services to all people-especially those who are vulnerable, oppressed, and living in poverty. The model that currently informs service delivery is unmistakably a business model. Respondents in this study appeared to have understood the importance of being knowledgeable about the business side of service delivery.

As a bridge between students, educators, agencies, and payers, field instructors offer valuable insight into the current service delivery climate. They are also firsthand witnesses to the challenges awaiting new and future social work practitioners. Their experience offers educators valuable information about the skills and knowledge which will allow social work practitioners to successfully function in these ever-changing environments and continue to serve vulnerable or oppressed clients. 
Respondents reached the greatest consensus regarding the need for and the importance of documentation as an essential basic skill in the current service delivery environment. This finding supports other research in suggesting that documentation ultimately protects clients, practitioners, and agencies (Houston-Vega et al., 1997; Kane et al., in press; Madden, 1998). Documentation provides an account of the provision of services, answers charges of malpractice, and evidences adherence to the standard of care (Houston-Vega et al., 1997; Kane et al., in press; Madden, 1998). Practitioners need specialized knowledge and skills to professionally interact in a society that has become increasingly litigious. By incorporating documentation requirements into the curriculum, social work educators are in a favorable position to ensure that students, clients, and agencies are protected. Although variation exists in documentation requirements for managed care and privatized environments, broad principles of responsible record keeping can be incorporated into coursework. Practitioners who function in managed care and privatized environments need basic familiarity with consents and releases, assessment tools, problem-oriented service plans, progress notes, treatment outcome documentation, termination summaries, and documenting critical incidents (Houston-Vega et al., 1997; Kane et al., in press; Madden, 1998). Traditional documentation methods, such as the S-O-A-P Method (Subjective, Objective, Assessment \& Plan) or the Problem-Oriented Medical Record Model, provide essential skills for current service delivery environments and agency reimbursement: that of charting-to-the-negative (Kane et al., in press). Educators may hesitate as they consider such strategies. However, the major challenge is to provide students with the skills to document in a problem-oriented fashion while remaining focused on client strengths and empowerment strategies. Perhaps the solution lies in honestly informing students of these existing tensions and noting that the language of service delivery environments and reimbursement is not necessarily the language of the profession (Kane et al., in press). If for no other reason, educators may wish to include content on documentation and liability to ensure that vicarious liability suits do not include their names for not having adequately prepared competent and responsible practitioners (Houston-Vega, Nuehring \& Kane, 1999).

The findings suggest that field instructors understand the important connection between practice and evaluation. Within social work education, research classes have been viewed as very distinct from and not practically connected to the remainder of the curricula. Respondent field instructors indicate that in current service environments practice and evaluation are inseparable. The study's findings support those of Volland et al. (1999) and suggest that content in the research sequence include strategies for intervention evaluation and outcome measures. There is nothing new in the concept that students need to understand: only practice that has been evaluated and examined is responsible practice (Berger \& $\mathrm{Ai}$, in press-b; Myers \& Thyer, 1997). For years these themes have been dominant in the educational literature. Perhaps actual evaluation and measurement of practice can be incorporated into the practice class, while the skills to perform the evaluative functions may be taught in the research sequence. These notions highlight the importance of empirically-based evaluation and its connection to practiceperhaps over other evaluative methods. One potential recommendation for ensuring 
that students understand the connection of practice to empirical evaluation is to ensure that they are concurrently enrolled in practice and evaluation courses.

Respondents identified time-focused and needs-based assessment as important. Social workers have a long history of assessing individuals, families, groups, organizations, and communities. Most practice texts identify assessment as an important function of social work, which remains ongoing in the helpingrelationship (cf: Hepworth, Rooney \& Larsen, 1997; Shulman, 1992; Woods \& Hollis, 1990). In managed care environments, the period in which the social worker has the opportunity to engage in a helping relationship is predicated on the client's acute need and is generally expected to be brief and time-limited. Identifying acute need is referred to as determining medical necessity and includes identifying health, mental health, and social service needs. Practitioners need the skills to quickly and accurately assess acute need, implement-attain-evaluate goals, and terminate the time-limited helping relationship. Managed care organizations view the assessment process as the shortest possible encounter in an acute situation in which the professional is able to accurately identify the problem and resolve it through an approved intervention.

Having noted the time constraints of the helping relationship from a managed care perspective, it is not surprising that respondents identified solution-focused methods and brief treatment as important practice models. A body of empirical literature supports the effectiveness of these practice models. Furthermore, managed care organizations may not allow providers to choose interventions which are not a part of the organization's approved list of treatment protocols (Davis \& Meiers, 2000). These protocols frequently include brief and solution-focused methodologies to the exclusion of others (Davis \& Meiers, 2000).

Field instructors identified knowledge of financing, insurance, managed care, entitlement programs, and the business-side of agency services as important. This appears consistent with their understanding that service environments operate from practice models as well as business models. These findings are consistent with those of Volland et al. (1999). Respondents, because of their connection to service delivery sites, provide valuable insight which suggests that practitioners in managed care and privatized environments need to be attentive to agency financial health and survival. A surprising element is that despite respondents' heightened awareness of the financial side of service delivery, only $66 \%$ of them identified knowledge of Medicare and Medicaid as important. This is particularly confusing as most respondents were employed in the private sector. Additionally, only $66 \%$ of respondents identified the skills to initiate macro changes as important in the current service environment.

Social work educators have understood that social work education is professional education, rather than purely academic education. Because social work curriculum prepares social work professionals, curriculum cannot remain isolated from the pressures of current service delivery needs and demands. Educators, as they view the realities of managed care and privatization, will understand the challenges of incorporating material in order that future practitioners remain in competitive positions for existing and future employment opportunities. 
Managed care organizations frequently allow the boundaries of various professions to blur in order to reduce cost and maximize profit.

While field instructors and service delivery environments offer important information for educators, educators must still contend with the issue of "how" to incorporate this material into curriculums in a meaningful manner. Undoubtedly, incorporating this material will require that educators choose managed care information over other material. Knowledge and skills, which were previously expected to be learned in the field site, may need to be formally incorporated into the classroom. This is particularly true of documentation skills, knowledge of business models, and general reimbursement information. Not unlike classroom educators, field instructors face similar time constraints as a result of the multiple demands placed on them. Previous research indicates that field instructors find it increasingly more difficult to provide intensive supervision and training to students (Berkman, 1996; Raskin \& Blome, 1996). With few other choices available, classroom educators may need to incorporate what has previously been covered in field supervision. Cooperative work in this fashion will alleviate notions of the disconnection between the field and the classroom and ensure that students receive the preparation they need to negotiate current service demands.

\section{References}

Alperin, D., Gray, S., \&Wik, R. (1991). Two models of social work field education: A multidimensional view. The Clinical Supervisor, 8(2), 5-18.

Beinecke, R. H., Goodman, M., \& Lockhart, A. (1998). The impact of managed care on Massachusetts mental health and substance abuse providers. In G. Shamess \& A. Lightburn (Eds.), Humane managed care? (pp. 145-155). Washington, DC: NASW Press.

Berger, C. S., \& Ai, A. (in press-a). Managed care and its implications for social work curricula reform: Clinical practice and field instruction. Social Work in Health Care.

Berger, C. S., \& Ai, A. (in press-b). Managed care and its implications for social work curricula reform: Policy and research initiative. Social Work in Health Care.

Berkman, B. (1996). The emerging health care world: Implications for social work practice and education. Social Work, 41(5), 541-551.

Borenstein, D. B. (1990). Managed care: Means of rationing psychiatric treatment. Hospitals and Community Psychiatry, 41, 1095-1098.

Brooks, D., \& Riley, P. (1996). The impact of managed health care policy on student field training. Smith College Studies in Social Work, 66(3), 307-316.

Callahan, J. (1998). Documentation of client dangerousness in managed care environment. In G. Schamess \& A. Lightburn (Eds.), Humane managed care? (pp. 299-307). Washington, DC: NASW Press.

Coggan, P. (1997). Medical education and marketplace competition. Journal of the American Medical Association, 277(13), 1037.

Corcoran, K., \& Gingerich, W. J. (1994). Practice evaluation in the context of managed care: Case recording methods for quality assurance reviews. Research on Social Work Practice, 4(3), 326-337.

Corcoran, K., \& Vandiver, V. (1996). Maneuvering the maze of managed care. New York: The Free Press.

Cowger, C. D. (1994). Assessing client strengths: Clinical assessment for client empowerment. Social Work, 39(3), 262-268.

Davidson, T., \& Davidson, J.R. (1998). Confidentiality and managed care: Ethical and legal concerns. In G. Schamess \& A. Lightburn (Eds.), Humane managed care? (pp. 281-292). Washington, DC: NASW Press. 
Davidson, T., Davidson, J.R., \& Keigher, S. M. (1999). Managed care: Satisfaction guaranteed... Not! Health and Social Work, 24(3), 163-168.

Davis, S. R., \& Meier, S. T. (2000). The elements of managed care: A guide for helping professionals. Stamford, CT: Brooks/Cole.

Dillman, D. A. (1978). Mail and telephone surveys: The total design method. New York: John Wiley \& Sons.

Donner, S. (1998). Fieldwork crisis: Dilemmas, dangers, and opportunities. In G. Schamess \& A. Lightburn (Eds.), Humane managed care?(pp. 442-454). Washington, DC: NASW Press.

Edinburg, G.M., \& Cottler, J. M. (1995). Managed care. In Encyclopedia of social work (Vol. 2, pp. 16351642). Washington, DC: NASW Press.

Elias, E., \& Navon, M. (1998). Managing organizational change: The Massachusetts Department of Mental Health experience in preparing for managed care. In G. Shamess \& A. Lightburn (Eds.), Humane managed care?( pp. 111-122). Washington, DC: NASW Press.

Fletcher, R. H. (1999). Who is responsible for the common good in a competitive market? Journal of the American Medical Association, 281(12), 1127 (1).

Gibelman, M., \& Schervish, P. H. (1997). Who we are-A second look. Washington, DC: NASW Press.

Ginsberg, L. H. (2000). Careers in social work (2nd ed.). Boston: Allyn and Bacon.

Hagland, M. (1996). Anything but academic. Hospitals \& Health Network, 70(1), 20 (6).

Hepworth, D. H., Rooney, R. H., \& Larsen, J. A. (1997). Direct social work practice: Theory and skills (5 $5^{\text {th }}$ ed.). Pacific Grove, CA: Brooks/Cole Publishing Company.

Houston-Vega, M.K., Nuehring, E. M., with Daguio, E.R. (1997). Prudent practice —A guide for managing malpractice risk. Washington, DC: NASW Press.

Houston-Vega, M. K., Nuehring, E. M., \& Kane, M. N. (1999, March). Liability in classroom teaching: A risk management framework. Paper presented at the Annual Program Meeting of the Council on Social Work Education, San Francisco, CA.

Kadushin, G. (1996). Adaptations of the traditional interview to the brief-treatment context. Families in Society: The Journal of Contemporary Human Services, 79(4), 346-357.

Kadushin, G. (1997). Educating students for a changing health care environment: An examination of health care practice course content. Health and Social Work, 22(3), 211-222.

Kane, M. N., Houston-Vega, M. K., \& Nuehring, E. M. (in press). Documentation in managed care: Challenges for social work education. Journal of Teaching in Social Work.

Kapp, M. B. (1999). Geriatrics and the law: Understanding patient rights and professional responsibilities. New York: Springer.

Kelly, P. (1998). Postmodern approaches: Education for a managed care environment. In G. Schamess \& A. Lightburn (Eds.), Humane managed care? (pp.430-441). Washington, DC: NASW Press.

Lee, J. B. (1994). The empowerment approach to social work practice. NewYork: Columbia University Press.

Madden, R. G. (1998). Legal issues in social work, counseling, and mental health. Thousand Oaks, CA: Sage Publications.

McEntee, C. (1993). Clinton's next moves: Scoping out the White House on health care reform. Hospitals, 67(2), 23-26.

McQuaide, S. (1999). A social worker's use of the “Diagnostic and Statistical Manual." Families in Society: The Journal of Contemporary Human Services, 80(4), 410-416.

Mitchell, C.G. (1998). Perceptions of empathy and client satisfaction with managed behavioral health care. Social Work, 43(5), 404-411.

Motenko, K., Allen, E., Angelos, P., Block, L., DeVito, J., Duffy, A., Holton, L., Lambert, K., Parker, C., Ryan, J., Schraft, D., \& Swindell, J. (1995). Privatization and cutbacks: Social work and client impressions of service delivery in Massachusetts. Social Work, 40(4), 456-463.

Munson, C.E. (1998). Evolution and trends in the relationship between clinical social work practice and managed care organizations. In G. Schamess \& A. Lightburn (Eds.), Humane managed care? (pp. 308324). Washington, DC: NASW Press. 
Myers, L.L., \& Thyer, B. A. (1997). Should social work clients have the right to effective treatment? Social Work, 42(3), 288-298.

National Association of Social Workers. (1996). NASW Code of Ethics. Washington, DC: Author.

Nordgren, R. (1996). The effect of managed care on undergraduate medical education. Journal of the American Medical Association, 275(13), 1053-1054.

O’Neill, J. (2000). Profession needs work force data. NASW News, 45(9), 1, 6.

Oss, M. E. (1996). Managed behavioral health care: A look at the numbers. Behavioral Health Management, 16(3), 16-17.

Parkeck, J. T., Murphy, J. W., \& Choi, J. M. (1994). Some implications of postmodernism for social work practice. Social Work, 39(4), 343-346.

Perloff, J. D. (1998). Medicaid managed care and urban poor people: Implications for social work. In G. Shamess, \& A. Lightburn (Eds.), Humane managed care? (pp. 65-74). Washington, DC: NASW Press.

Poole, D. L. (1996). Keeping managed care in balance. Health and Social Work, 21(3), 163-166.

Rapp, C. A. (1998). The strengths model: Case management with people suffering from severe and persistent mental illness. New York: Oxford University Press.

Raskin, M. S., \& Blome, W. W. (1998). The impact of managed care on field instruction. Journal of Social Work Education, 34(3), 365-374.

Reamer, F. G. (1998). Managed care: Ethical considerations. In G. Shamess \& A. Lightburn (Eds.), Humane managed care? (pp. 293-298). Washington, DC: NASW Press.

Rock, B., \& Congress, E. (1999). The new confidentiality for the 21st century in a managed care environment. Social Work, 44(13), 253-262.

Rose, S.J. (1996). Managing mental health: Whose responsibility? Health \& Social Work, 21(1), 76-80.

Rosenberg, G. (1998). Social work in health and mental health managed care environment. In G. Shamess \& A. Lightburn (Eds.), Humane managed care? (pp. 3-22). Washington, DC: NASW Press.

Rubin, A., \& Babbie, E. (2000). Research methods for social work (4th ed.). Belmont, CA: Wadsworth/Thomson Learning.

Saleebey, D. (1996). The strengths perspective in social work practice: Extensions and cautions. Social Work, 39(5), 580-587.

Scuka, R. F. (1994). Health care reform in the 1990s: An analysis of the problems and three proposals. Social Work, 39(5), 580-587.

Sessions, P. (1998). Managed care and the oppression of psychiatrically disturbed adolescents: A disturbing example. In G. Shamess \& A. Lightburn (Eds.), Humane managed care? (pp. 171-179). Washington, DC: NASW Press.

Shera, W. (1996). Managed care and people with severe mental illness: Challenges and opportunities for social work. Health and Social Work, 21(3), 196-201.

Shulman, L. (1992). The skills of helping: Individuals, families and groups (3rd ed.). Itasca, IL: F. E. Peacock Publishers, Inc.

Strom-Gottfried, K. (1997). The implications of managed care for social work education. Journal of Social Work Education, 33(1), 7-18.

Valland, P. J., Berkman, B., Stein, G., \& Vaghy, A. (1999). Social Work Education for Practice in Health Care: Final Report-A Project of the New York Academy of Medicine. New York: Authors.

Vandivort-Warren, R. (1996). CSWE/NASW report on preparing social workers for a managed care environment. Washington, DC: National Association of Social Workers.

Vernon, D. M. (1998). New opportunities for social work with state Medicaid managed care providers. In G. Shamess \& A. Lightburn (Eds.), Humane managed care? (pp. 401-406). Washington, DC: NASW Press.

Watt, J. W., \& Kallmann, G. L. (1998). Managing professional obligation under managed care: A social work perspective. Family and Community Health, 21(2), 40-49. 
White, M., Simmons, W. J., \& Bixby, N. (1993). Managed care and case management: An overview. Discharge Planning Update, 13(1), 17-19.

Woods, M. E., \& Hollis, F. (1990). Casework: A psychosocial therapy (4th ed.). New York: McGraw-Hill, Inc.

\section{Author's Note:}

Address correspondence to: Michael N. Kane, Ph.D., 7311 Lyons Road, Coconut Creek, Florida 33073-4331 USA. 